\title{
The Effect of BI Rate, USD to IDR Exchange Rates, and Gold Price on Stock Returns Listed in the SRI KEHATI Index
}

\author{
Oktavian Yodha Utama ${ }^{\bowtie}$, Siti Puryandani \\ Management Department, STIE Bank BPD Jateng, Semarang, Indonesia
}

\begin{tabular}{l} 
Info Article \\
History Article: \\
Submitted 23 September 2019 \\
Revised 11 December 2019 \\
Accepted 13 December 2019 \\
\hline Keywords: \\
Stock Returns; BI Rate; USD to \\
IDR Exchange Rate; Gold Price; \\
SRI KEHATI Index.
\end{tabular}

History Articl :

Submitted 23 September 2019

Revised 11 December 2019

Accepted 13 December 2019

Stock Returns; BI Rate; USD to

SRI KEHATI Index.

\begin{abstract}
This study aims to determine the effect of BI rate, USD to IDR exchange rates, and gold price on stock returns listed in the SRI KEHATI Index for the period January to December 2018. The population in this research is companies listed on the Indonesia Stock Exchange. The sample is determined by using a purposive sampling method. Some criteria of the sample are companies that: had entered to the SRI KEHATI index respectively from January to December 2018, reported the 2018 monthly financial report, were not suspended by the IDX during the study period, so that obtained a sample of 23 companies with total data is 268 . This study used quantitative data analysis in the form of time-series data from January to December 2018. The data collection method used in this study is the documentation method. The analytical tool in this study is the multiple regression analysis. In this study, data is processed by using the SPSS program 21. The results show that the BI rate has a significant positive effect on stock returns, the USD to IDR exchange rate has a significant negative effect on stock returns, and gold price does not have a significant effect on stock returns.
\end{abstract}

\section{Pengaruh BI Rate, Kurs USD/IDR, dan Harga Emas Dunia terhadap Return Saham yang Terdaftar dalam Indeks SRI-KEHATI}

\begin{abstract}
Abstrak
Penelitian ini bertujuan untuk mengetahui pengaruh Suku Bunga BI, Kurs USD/IDR, dan harga emas terhadap return saham yang terdaftar di dalam Indeks SRI-KEHATI Periode Januari hingga Desember 2018. Populasi dalam penelitian ini adalah seluruh perusahaan yang terdaftar di BEI. Sampel ditentukan menggunakan metode purposive sampling dengan kriteriakriteria antara lain perusahaan yang masuk ke dalam indeks SRI-KEHATI secara berturutturut pada Januari-Desember 2018, perusahaan yang melaporkan hasil laporan keuangan bulanan periode 2018, Perusahaan yang tidak disuspensi oleh BEI selama periode penelitian, sehingga diperoleh sampel sebanyak 23 perusahaan dengan jumlah data 268. Dalam penelitian ini menggunakan analisa data kuantitatif berupa data runtut waktu. Metode pengumpulan data dalam penelitian ini adalah metode dokumentasi. Alat analisis pada penelitian ini adalah analisis regresi berganda. Olah data pada penelitian ini menggunakan program SPSS 21 . Hasil menunjukkan bahwa Suku Bunga BI berpengaruh positif signifikan terhadap return saham, Kurs USD/IDR berpengaruh negatif signifikan terhadap return saham, dan harga emas tidak berpengaruh terhadap return saham.
\end{abstract}

JEL Classification: E43, L7, O24

How to Cite: Utama, O. Y., \& Puryandani, S. (2020). The Effect of BI Rate, USD to IDR Exchange Rates, and Gold Price on Stock Returns Listed in the SRI KEHATI Index. Jurnal Dinamika Manajemen, 11(1), 39-47. 


\section{INTRODUCTION}

Nowadays, the development of the capital market in Indonesia can be said to be rapid. Many new investors are interested in investing their funds in the capital market through stock investments. The condition of the capital market in Indonesia is reflected in the stock price index. Activities that occur in the capital market are supply and demand activities between investors who have excess funds and companies that need funds. By doing these activities as investors expect returns on stock investments that they have made to companies that need funds. The stock return they expect is capital gains and dividend distribution by the company to shareholders.

Before investing in the capital market, investors will usually be influenced by information contained in the stock price index. Investors will see stock price movements to the trade-off between the risks and returns they will receive for their investment decisions. Inside the Indonesia Stock Exchange (IDX), there are 22 classifications of the stock index. One of them is the SRI KEHATI stock index. The SRI KEHATI Index is an index that measures the performance of stock prices of 25 companies who have excellent performance in encouraging sustainable business and have a good awareness of the environment, social and corporate governance, or referred to as Sustainable and Responsible Investment (SRI). Yayasan Keanekaragaman Hayati Indonesia is an institution that launches and manages the SRI KEHATI Index. Besides, no research has been conducted by using the return of the SRI KEHATI Index. Figure 1 is the SRI KEHATI stock index movement from January to December 2018.

The graph shown in Figure 1 is a graph of the movement of the SRI KEHATI stock index for the period January to December 2018. The graph moves lucratively or up and down. The stock price fluctuation in the SRI KEHATI index makes the stock returns obtained can increase and decrease. The shares in the SRI KEHATI index consist of various sectors of the company's shares, such as financial, mining, food and beverages and so on. The ups and downs of stock price movements in the SRI KEHATI index are mainly influenced by Indonesia's macroeconomic development factors such as the rate of movement of central bank interest rates, currency exchange rates, inflation, stock indices on the world market, world energy prices, security, and political conditions.

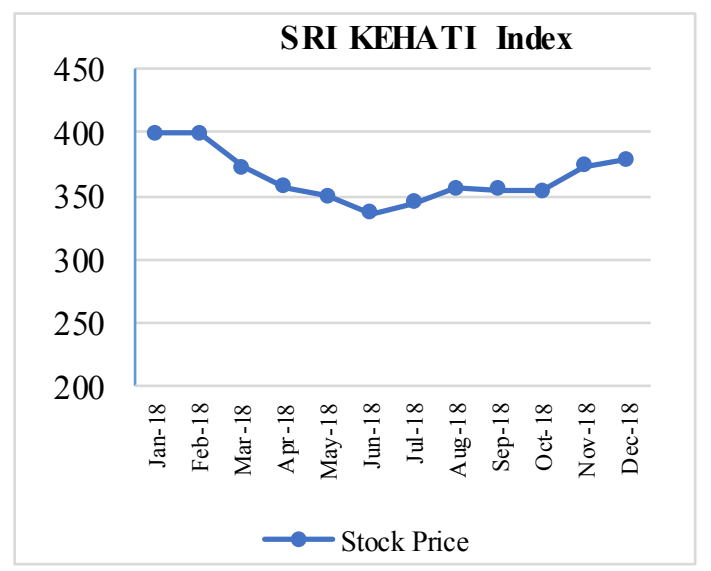

Figure 1. The movement of the SRI KEHATI Stock Index for the period of January 2018 to December 2018

Some studies explain macroeconomic factors influence stock returns. Some studies resulted that the BI rate has a negative effect on stock return (Gumilang et al., 2014; Apriyani et al., 2018). On the contrary, the result of some studies stated that the BI rate has a positive effect on stock return (Wiradharma \& Sudjarni, 2016; Hidayat et al., 2017). The other research conducted by some researchers resulted that the BI rate did not significantly influence stock return (Rahman \& Khairunnisa, 2016; Widya, Adnyana, Suwena, \& Sujana, 2017; Andes, Puspitaningtyas, \& Lukman, 2017; Afiyanti \& Topowijono, 2018; Rozi, 2018; Widhiatmoko \& Dillak, 2018; Yunita, Nurlita, \& Robiyanto, 2018; Yunita \& Robiyanto, 2018). An increase in the USD / IDR exchange rate has negative effect on stock return (Gumilang et al., 2014; Widya et al., 2017; Andes et al., 2017; Widhiatmoko \& Dillak, 2018; Yunita et al., 2018; Yunita \& Robiyanto, 2018; Robiyanto, 2018b). 
A different result of research stated that USD/ IDR exchange rate has a positive effect on stock return (Handiani, 2014; Apriyani et al., 2018; Afiyanti \& Topowijono, 2018; Prasetioningsih, 2018). The other research resulted that the USD/IDR exchange rate did not significantly influence stock return (Wiradharma \& Sudjarni, 2016; Rahman \& Khairunnisa, 2016; Hidayat et al., 2017; Rozi, 2018).

Previous studies show that the results obtained are inconsistent. This can occur because of differences in the object under study, differences in data analysis techniques and different periods used. Besides, the lack of other previous studies is the ability of models to explain factors that affect stock returns is still low, so it is necessary to use other variables, like the price of world commodities such as prices of gold, copper, palladium, crude oil, and other commodity prices. The novelty of this article is that it takes the gold price as one of the research variables. Based on previous studies resulted inconsistent results between one and another, and there are suggestions from previous researchers to add other variables in the study to explain the factors that influence stock returns clearly, then researchers are interested in conducting research more.

The objective of this study is to find out the effect of BI Rate, USD to IDR Exchange Rates, and Gold Price on Stock Returns. Hopefully, this research is expected to help decision making based on macroeconomic factors such as BI Rate, USD to IDR Exchange Rates, and Gold Price on Stock Returns, especially in the SRI KEHATI Index.

\section{Hypothesis Development \\ BI Rate and the Return of SRI KEHATI Stock Price Index}

The movement of the BI rate is used as a reference for the size of other interest rates, so that when the BI rate increases, other interest rates will also increase. Changes in BI interest rates can affect a company's stock returns. When the BI interest rate increases, the profit of the company will decreases because the company must pay interest costs. The higher interest cost makes the production cost become higher and causes the selling price of products to become more expensive. Customers will tend to hold purchase. which means will decrease the number of product sales, then the company's profit will be cut so it will influence the company's stock price. This indicates that an increase in the BI rate will reduce the company's stock return (Gumilang et al., 2014; Apriyani et al., 2018; Robiyanto, 2018b; Yunita \& Robiyanto, 2018). Therefore, the hypothesis is:

H1: BI rate has a negative effect on SRI KEHATI stock price index return.

\section{USD/IDR Exchange Rate and the Return of SRI KEHATI Stock Price Index}

The form of the exchange rate itself is the value of a country's currency that can be exchanged for another country's currency. The exchange of these currencies is known as forex transactions. If the foreign currency exchange rate increases, then the value of the domestic currency will surely decrease (depreciated) so that the price of raw materials and imported goods will rise, which causes higher production costs, and the company's profit will decrease. The decline in the company's profit causes the company's stock price reduced. This indicates that the increase in foreign currency exchange rates will reduce the company's stock return (Gumilang et al., 2014; Andes et al., 2017; Widya et al., 2017; Robiyanto, 2018b; Widhiatmoko \& Dillak, 2018; Yunita et al., 2018; Yunita \& Robiyanto, 2018). Therefore, the hypothesis is:

H2: USD/IDR exchange rate has a negative effect on SRI KEHATI stock price index return.

\section{Gold Price and the Return of SRI KEHATI Stock Price Index}

In the SRI KEHATI index, there are several corporate sectors such as mining, finance, manufacture, etc. The increase in world gold prices will have an impact on the development of a country's macro economy. When the price of 
gold rises, it tends to be followed by an increase in the domestic exchange rate. The strengthening of the domestic currency reflects economic growth in a country that can be said is being excitement. The appreciation of the domestic currency makes production cost in companies listed in the SRI KEHATI index decline and causes the level of profitability obtained by the company to increase. The rise of the company's profit will be followed by an increase in the company's stock price. The rise of the company's stock price will be followed by an increase in stock returns. This indicates that the increase in gold prices will have a positive effect on the company's stock return. This argument is reinforced by the result of research conducted by some researchers (Handiani, 2014; Robiyanto, 2018b; Rozi, 2018; Yunita et al., 2018). Moreover, the research conducted by Baur and McDermott (2010) resulted that gold has a positive effect on the return of the composite stock index of Australia, Canada, and Japan. Gold has a positive impact on the return of the composite stock index of China (Arouri et al., 2015). Another research resulted that gold has a positive impact on the Indonesian Composite Stock Index (Robiyanto, 2018a). Therefore, the hypothesis is:

H3: The Gold price has a positive effect on SRI KEHATI stock price index return.

Based on the hypothesis development above, the research framework can be seen in Figure 2.

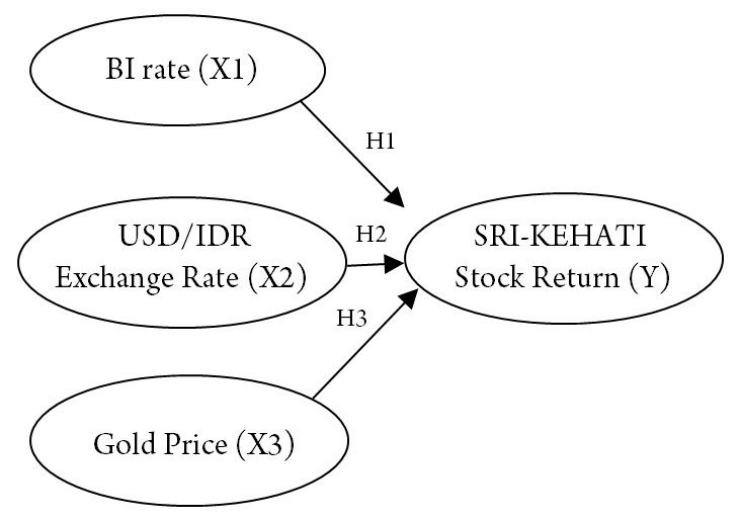

Figure 2. Model Framework

\section{METHOD}

This research is using a quantitative method using time series data because the data is obtained from January to December 2018. The study observes the relation between BI rate, USD/IDR exchange rate and gold price towards the return of SRI KEHATI index.

The population in this research is all companies listed on the Indonesia Stock Exchange. SRI KEHATI index is chosen to be the object of this research because in the SRI KEHATI index, 25 companies have implemented the CSR and sustainability of the environment. We have the independent variables that might influence CSR and sustainability of the environment. For example, the gold price variable will be influenced by the availability of the gold source, as the mining company that joined in SRI KEHATI index they have to implement the sustainability factors, so this variable has the potency to influence the stock return of mining companies that entered in SRI KEHATI index. Moreover, the $\mathrm{BI}$ rate and exchange rate will influence the production process in the companies that entered in SRI KEHATI index. Then, the sample is determined by using purposive sampling method with criteria such as: companies that had entered to the SRI KEHATI index from January to December 2018, companies that entered to the SRI KEHATI index respectively from January to December 2018, companies that reported the 2018 monthly financial report, companies that were not suspended by the IDX during the study period so that obtained a sample of 23 companies with total data is 268 .

The data used in this study is secondary data, where the stock return data use 2018 monthly closing stock price, which obtained monthly report statistics of IDX. BI rate data obtained from a 7-days repo rate from January 2018 to December 2018 sourced by bi.go.id. USD/IDR exchange rate data obtained from Bank Indonesia's official website (www.bi.go. id) from January 2018 to December 2018. Gold price data use 2018 monthly gold price, which obtained from Investing.com. 
In this study, a dependent variable used is the stock return that obtained from the changes in the closing price of shares listed in the SRIKEHATI index for the period January 2018 to December 2018, which is calculated with:

$$
\mathrm{R}_{\mathrm{i}, \mathrm{t}}=\frac{P_{i, t}-P_{i, t-1}}{P_{i, t-1}}
$$

Notes:

Ri,t $\quad=$ Return of financial sector stock price index in $t$ period (in percent)

$\mathrm{Pi}, \mathrm{t} \quad=$ Financial sector stock price index in $\mathrm{t}$ period (in Rupiah)

$\mathrm{Pi}, \mathrm{t}-1=$ Financial sector stock price the index in $\mathrm{t}-1$ period (in Rupiah)

Then the independent variables used in this study BI rate, USD to IDR exchange rates, and gold price. BI rate is the cost for debts to be paid (in percent). BI rate data is obtained from the 7-days repo rate sourced from bi.go.id. USD/IDR exchange rate is the value of USD/ IDR from time to time. The data of the USD/ IDR exchange rate is obtained from the Bank Indonesia website for January 2018 to December 2018. This research also using world gold prices from January 2018 to December 2018. Data of gold price is obtained from the site www.investing.com during the period January 2018 to December 2018.

The analysis technique used to solve the problems in this study is multiple linear regression using SPSS 21(Statistical Package for Social Science) computer program assistance. Multiple linear regression analysis is used to measure the strength of the relationship between two or more variables and shows the direction of the relationship between the dependent variable and independent variables (Ghozali, 2011). This study consists of three independent variables such as BI rate (X1), USD/IDR exchange rate (X2), Gold Price (X3) and one dependent variable is Stock Return (Y). The multiple linear regression equation models in this study can be formulated as follows:

$$
\mathrm{Y}=\alpha+\beta 1 \mathrm{X} 1+\beta 2 \mathrm{X} 2+\beta 3 \mathrm{X} 3+\varepsilon
$$

Notes:

$\mathrm{Y} \quad=$ Stock return

a $\quad=$ Constant

$\mathrm{X} 1=$ BI Rate

$\mathrm{X} 2=\mathrm{USD} / \mathrm{IDR}$ exchange rate

$\mathrm{X} 3=$ Gold price

$\beta 1-\beta 3=$ Regression coefficient of each independent variable

$\varepsilon \quad=$ Error term

\section{RESULT AND DISCUSSION}

\section{Result of Multiple Regression Analysis}

Based on the result of multiple regression in Table 1, analysis can be formed regression equation as follows:

$\mathrm{Y}=0.776+0.067 \mathrm{X} 1-0.000075 \mathrm{X} 2-0.000046 \mathrm{X} 3+\varepsilon$

Notes:

$\mathrm{Y} \quad=$ Stock return

a $\quad=$ Constant

$\mathrm{X} 1=$ BI Rate

$\mathrm{X} 2=\mathrm{USD} / \mathrm{IDR}$ exchange rate

$\mathrm{X} 3=$ Gold price

$\beta 1-\beta 3=$ Regression coefficient of each independent variable

$\varepsilon \quad=$ error term

\begin{tabular}{|c|c|c|c|c|c|}
\hline \multirow{2}{*}{ Model } & \multicolumn{2}{|c|}{ Unstandardized Coefficients } & \multirow{2}{*}{$\begin{array}{c}\text { Standardized Coefficients } \\
\text { Beta }\end{array}$} & \multirow{2}{*}{$\mathbf{t}$} & \multirow{2}{*}{ Sig. } \\
\hline & B & $\begin{array}{c}\text { Std. } \\
\text { Error }\end{array}$ & & & \\
\hline (Constant) & .776 & .561 & & 1.382 & .168 \\
\hline \multirow{3}{*}{$\begin{array}{l}\text { BI Rate } \\
\text { USD/IDR Exchange Rate } \\
\text { Gold Price }\end{array}$} & .067 & .016 & .549 & 4.085 & .000 \\
\hline & -.000075 & .000 & -.467 & -2.885 & .004 \\
\hline & -.000046 & .000 & -.028 & -.209 & .835 \\
\hline
\end{tabular}

Table 1. Result of Multiple Regression Analysis 
The value of the BI regression coefficient on SRI KEHATI stock return is 0.067 , with a $\mathrm{t}$-value counted 4.085 , which is significant at a $1 \%$ significance level. Based on this, $\mathrm{H} 1$ which states that the BI rate has a negative effect on THE SRI KEHATI stock price index return is rejected. The result states that if there is an increase in the BI rate, then there is an increase in the SRI KEHATI stock return. The reasons why in 2018 when BI rate increased, the SRI KEHATI stock return also increased are firstly in the SRI KEHATI index consist of five reputable banking companies such as Bank Central of Asia (BBCA), Bank Negara Indonesia (BBNI), Bank Rakyat Indonesia (BBRI), Bank Mandiri (BMRI), and Bank Danamon (BDNM). All of them had good financial performance in 2018. They had lend credit to the debtor successfully. They had owned the profitability from the interest rate that they charged to the debtor. The Non-Performing Loan rate in those companies decreased. Therefore, this case made the investor didn't withdraw their stock in those companies even though there was an increase in the BI rate.

Secondly, the sales growth in manufacture companies that entered in SRI KEHATI index happened surprisingly. For example, in 2018 the sales growth of PT Indofood CBP Sukses Makmur Tbk (ICBP) increased to 7.9\% (Alfi, 2019). As the investors saw this case as an advantage for them. By seeing this case, they tend to hold their stock in ICBP, which became one of the companies listed in the SRI KEHATI index. So it can be concluded that in 2018 mostly the financial performance of the companies listed in the SRI KEHATI index was good. Besides, this finding is consistent with the previous research result, which stated that the BI rate has a positive effect on stock return (Wiradharma \& Sudjarni, 2016; Hidayat et al., 2017). Signaling theory emphasizes the importance of information issued by issuers on the results of investor investment decisions. Company management always publishes the information needed by investors, especially if the information is good news. All information about the company is a signal for investors to determine their investment decisions. The monthly report of companies listed in the SRI KEHATI had made the investors still hold their investment stock in companies listed in the SRI KEHATI index because the information that they got was good news. And it is consistent with the explanation of the signaling theory.

The value of the USD/IDR exchange rate regression coefficient on the SRI KEHATI stock return equation is -0.000075 , with a $\mathrm{t}$-value of -2.885 which is significant at a $1 \%$ significance level. Based on this, $\mathrm{H} 2$ which states that the USD/IDR exchange rate has a negative effect on the SRI KEHATI stock return, cannot be rejected. This is because if the value of the rupiah decreases, the people will switch to buy currency US Dollars so that the capital market does not have an appeal because of the return on the purchase of foreign currency generates a higher return compared to buying and selling shares. Besides, that reason also strengthened by the fact in the field, in 2018 The SRI KEHATI index dropped slightly to $-4.26 \%$ (Investing.com, 2018). It means that when rupiah was depreciated, investors tend to invest their funds in US Dollars that will give more return than invest in stocks. Therefore, this case makes the $\mathrm{H} 2$ which states that the USD/IDR exchange rate has a negative effect on the SRI KEHATI stock return is accepted and this finding is consistent with the previous research result (Gumilang et al., 2014; Andes et al., 2017; Widya et al., 2017; Robiyanto, 2018b; Widhiatmoko \& Dillak, 2018; Yunita et al., 2018; Yunita \& Robiyanto, 2018).

Signaling theory also explained that the sender of information tries to provide relevant information that can be utilized by the recipient of the information. The recipient of the information will then adjust his behavior according to his/her understanding of the signal. Here the information about the depreciation of the $\mathrm{Ru}$ piah exchange rate to the US Dollar gave the negative signal to the investors because they were thought that investing in forex will give more return than in stock. It was reflected in 2018 
Oktavian Yodha Utama \& Siti Puryandani/ The Effect of BI Rate, USD to IDR Exchange Rates ...

that the SRI KEHATI index dropped slightly to $-4.26 \%$ (Investing.com, 2018). The value of the gold price coefficient on SRI KEHATI stock return is -0.000046 with $\mathrm{t}$-value counted -0.209 , which is not significant at a $5 \%$ significance level because the value of significance level of the gold price is 0.835 or above $5 \%$ significance level. Based on this, $\mathrm{H} 3$ which states that gold price has a positive effect on SRI KEHATI stock price index return is rejected. There is no influence of gold price on the SRI KEHATI Index. It happened because gold and stock are different investment instruments, and also, there was an increase in the SRI KEHATI Index from 2017 to 2018, around 4.23\% (Investing.com, 2018). This number made the investors didn't want to switch their investment instrument because the performance of companies that listed in SRI KEHATI index was good. An increase or decrease of gold price didn't influence the stock return of the SRI KEHATI index. This finding is strengthening the previous research result, which stated that gold price did not significantly influence stock return ( Baur \& Lucey, 2010; Krondahl \& Lindahl, 2012; Raraga et al., 2012; Wang, 2012; Agyei-Ampomah et al., 2014; Bredin et al., 2015; Husnul, et al., 2017).

Market efficiency theory is a theory that discusses the availability of information related to prices or the value of securities that exist in the market (Hanafi, 2004). Forms of market efficiency in terms of information are divided into; market efficiency is weak, semi-strong, and strong (Jogiyanto, 2010). As the companies listed in the SRI KEHATI index tried to give full information to the investors. Furthermore, in this case, investors entered the strong market, and make the information about an increase or decrease of the gold price has no impact on the information in the capital market especially in the SRI KEHATI index. Because of the full information about companies in SRI KEHATI Index made the investors still hold their stock investment. Based on the discussion above, it reflects that market efficiency theory, signaling theory, and prospect theory are used in decision making.

\section{CONCLUSION AND RECOMMENDATION}

The results of this study indicate that $\mathrm{BI}$ rate has a significant positive effect on SRI KEHATI stock return. Then, USD/IDR exchange rate has a significant negative effect on SRI KEHATI stock return. While gold price did not significantly influence SRI KEHATI stock returns. An increase in gold price will cause investors to divert their investments. This is because gold has a lower risk than investment in the capital market but can provide good profits with price increases, which means there is no relation between gold price and stock return. The findings in this study imply that investors in the Indonesia Stock Exchange should pay attention to changes in USD/IDR rate and BI rate. If there is a strengthening of the USD/IDR exchange rate, then investors are better to sell their stocks because the strengthening of the USD/IDR exchange rate will decrease SRI KEHATI stock return, the same is necessary if there is an increase in BI rate will increase SRI KEHATI stock return, so investors are better to buy stocks in capital market.

Future research is recommended to use a longer period of research to know the impact of the variables studied on SRI KEHATI index in the long run. Future research can also use moderating variables to strengthen the relation among USD/IDR exchange rate, BI rate, and gold price to the stock return. Furthermore, it is recommended to use other variables such as market risk and Gross National Product (GNP) and using other sector's stock price index such as manufacture, mining, etc. In addition, investor are recommended not to invest in financial sector stock when the value of USD appreciated or Rupiah exchange rate depreciated because of it has negative effect on financial sector stock price index return.

\section{REFERENCES}

Afiyanti, H. T., \& Topowijono. (2018). Pengaruh Inflasi, BI Rate dan Nilai Tukar terhadap Return Saham (Studi pada Perusahaan Subsektor Food \& Beverages yang Terdaftar di Bursa 
Efek Indonesia Periode 2013-2016). Jurnal Administrasi Bisnis, 61(2), 136-143.

Agyei-Ampomah, S., Gounopoulos, D., \& Mazouz, K. (2014). Does Gold Offer Better Protection against Losses in Sovereign Debt Bonds than Other Metals?. Journal of Banking and Finance, 40(1), 507-521.

Alfi, A. N. (2019, March). KINERJA 2018: Penjualan ICBP Tumbuh 7,9\% Jadi Rp38,41 Triliun. Bisnis.Com. Available at: https://market.bisnis.com/read/20190322/192/903132/kinerja-2018-penjualan-icbp-tumbuh-79-jadirp3841-triliun. 20 August 2020.

Andes, P., Puspitaningtyas, Z., \& Lukman, S. (2017). Pengaruh Inflasi, Kus Rupiah, dan Suku Bunga terhadap Return Saham Perusahaan Manufaktur. Jurnal Akuntansi Keuangan dan Bisnis, 10(2), 8-16.

Apriyani, N., Rindayati, W., \& Wiliasih, R. (2018). Analisis Pengaruh Variabel EPS dan Makroekonomi terhadap Return Saham Jakarta Islamic Index Sektor Pertanian. Jurnal AlMuzara'ah, 3(1), 44-61.

Baur, D. G., \& Lucey, B. M. (2010). Is Gold a Hedge or a Safe Haven? an Analysis of Stocks, Bonds, and Gold. The Financial Review, 45(3), 217229.

Baur, D. G., \& McDermott, T. K. (2010). Is Gold a Haven? International Evidence. Journal of Banking and Finance, 34(8), 1886-1898.

Bredin, D., Conlon, T., \& Potì, V. (2015). Does Gold Glitter in the Long-run? Gold as a Hedge and Haven Across Time and Investment Horizon. International Review of Financial Analysis, 41(C), 320-328.

Arouri, M. E. H., Lahiani, A., \& Nguyen, D. K. (2015). World Gold Prices and Stock Returns in China: Insights for Hedging and Diversification Strategies. Economic Modelling, 44(January), 273-282.

Ghozali, I. (2011). Aplikasi Analisis Multivariate dengan Program SPSS (Kelima). Semarang: Universitas Diponegoro.

Gumilang, R. C., Hidayat, R. R., \& N P, M. G. W. E. (2014). Pengaruh Variabel Makro Ekonomi, Harga Emas dan Harga Minyak Dunia terhadap Indeks Harga Saham Gabungan (Studi pada Bursa Efek Indonesia Periode 20092013). Jurnal Administrasi Bisnis (JAB), 14(2), $1-9$.

Hanafi. (2004). Manajemen Keuangan. Yogyakarta: BPFE UGM.
Handiani, S. (2014). Pengaruh Harga Emas Dunia, Harga Minyak Dunia dan Nilai Tukar Dolar Amerika/Rupiah terhadap Indeks Harga Saham Gabungan pada Periode 2008-2013. EJournal Graduate Unpar, 1(1), 94-105.

Hidayat, L. R., Setyadi, D., \& Azis, M. (2017). Pengaruh Inflasi dan Suku Bunga dan Nilai Tukar Rupiah serta Jumlah Uang Beredar terhadap Return Saham. Forum Ekonomi, 19(2), 148154.

Husnul, H. M., Hidayat, R. R., \& Sulasmiyati, S. (2017). Analisis Pengaruh Inflasi, Kurs (IDR/ USD), Produk Domestik Bruto dan Harga Emas Dunia terhadap Indeks Harga Saham Gabungan (Studi pada Indonesia Periode 2008 - 2016). Jurnal Administrasi Bisnis (JAB), $53(1), 66-74$.

Investing.com. (2018). Data Historic IDX SRI-KEHATI. Available at: https://id.investing.com/ indices/sri-kehati-historical-data. 1 March 2020.

Jogiyanto, H. (2010). Teori Portofolio dan Analisis Investasi (Ketujuh). Yogyakarta: BPFE.

Krondahl, E., \& Lindahl, O. (2012). Perceptual Safe Havens: a Study of Gold, Oil, Palladium, Wheat, Bonds, USD, and Stocks. Thesis. Lund University.

Prasetioningsih, D. (2018). Pengaruh Nilai Tukar Rupiah terhadap Return Saham yang Terdaftar di Bursa Efek Indonesia (Studi Kasus Perusahaan LQ45 Periode Januari 2012-Desember 2015). Journal of Management, 4(4), $1-10$.

Rahman, G. D., \& Khairunnisa. (2016). Pengaruh Tobin's Q Inflasi, Suku Bunga, dan Nilai Tukar terhadap Return Saham (Studi pada Perusahaan Manufaktur yang Terdaftar di Bursa Efek Indonesia Tahun 2011-2014). E-Proceeding of Management, 3(1), 331-338.

Raraga, F., Chabachib, M., \& Muharam, H. (2012). Analisis Pengaruh Harga Minyak dan Harga Emas terhadap Hubungan Timbal-balik Kurs dan Indeks Harga Saham Gabungan (IHSG) di Bursa Efek Indonesia (BEI) 2000-2013. Jurnal Bisnis Strategi, 21(1), 72-94.

Robiyanto, R. (2018a). Gold VS Bonds: What is the Safe Haven for the Indonesian and Malaysian Capital Market? Gadjah Mada International Journal of Business, 20(3), 277-302.

Robiyanto, R. (2018b). The Effect of Gold Price Changes, USD/IDR Exchange Rate Changes and Bank Indonesia (BI) Rate on Jakarta 
Oktavian Yodha Utama \& Siti Puryandani/ The Effect of BI Rate, USD to IDR Exchange Rates ...

Composite Index (JCI)'S Return and Jakarta Islamic Index (JII)'S Return. Jurnal Manajemen dan Kewirausahaan, 20(1), 45-52.

Rozi, A. (2018). Anlisis Tingkat Suku Bunga BI, Kurs Rupiah, Harga Emas Dunia, Harga Minyak Dunia, Indeks Hang Seng terhadap Indeks Harga Saham Gabungan (Studi Kasus pada IHSG di Bursa Efek Indonesia Periode 20052012). Jurnal Manajemen Jambi, 1(2), 1-11.

Wang, L. (2012). Investment in Gold: an Empirical Study of the Gold Return from the 90s to 21st. Working Paper Copenhagen Business School.

Widhiatmoko, S. W., \& Dillak, V. J. (2018). Pengaruh Inflasi, Kurs Valuta Asing, dan Tingkat Suku Bunga SBI terhadap Return Saham (Studi pada Perusahaan Sektor Properti yang Terdaftar di BEI Tahun 2013-2016). E-Proceeding of Management, 5(2), 2172-2179.

Widya, P., Adnyana, P., Suwena, K. R., \& Sujana, I. N. (2017). Pengaruh Tingkat Inflasi, Suku
Bunga, dan Kurs Valuta Asing terhadap Return Saham pada Perusahaan Property dan Real Estate di Bursa Efek Indonesia Periode 2012-2016. Ejournal Jurusan Pendidikan Ekonomi, 10(2), 267-278.

Wiradharma, M. S., \& Sudjarni, L. K. (2016). Pengaruh Tingkat Suku Bunga, Inflasi, Nilai Kurs Rupiah, dan Produk Domestik Bruto terhadap Return Saham. E-Journal Manajemen UNUD, 5(6), 3392-3420.

Yunita, Y., Nurlita, E., \& Robiyanto, R. (2018). Pengaruh Suku Bunga, Kurs Rupiah, dan Harga Emas terhadap Return Saham Sektor Pertambangan di Bursa Efek Indonesia. Proceeding SENDI-U, UNISBANK, 978-979.

Yunita, Y., \& Robiyanto, R. (2018). The Influence of Inflation Rate, Bi Rate, and Exchange Rate Changes to the Financial Sector Stock Price Index. Jurnal Manajemen dan Kewirausahaan, 20(2), 80-86. 